\title{
Factors Associated with Sodomy Cases at a Tertiary Care Hospital of Karachi
}

\author{
Abdul Waheed, Mir Ghulam Ali Talpur, Iqbal Ahmed Khan, Hari Ram, Shahid Nezam, Syed Pervaiz Alam
}

ABSTRACT

Objective: To observe the number of sodomy cases and their associated factors reported to Abbasi Shaheed Hospital for medicolegal examination in Karachi.

Study design and setting: The retrospective study design conducted at medicolegal section of Abbasi Shaheed Hospital Karachi from January 2016 till December 2018 reported from 45 different police stations of Karachi.

Methodology: This was a single centred study on sodomy conducted by using non-probability sampling technique. Data was collected from medico legal section of Abbasi Shaheed Hospital, Karachi, from a period of January 2016 till December 2018 reported from 45 different police stations of Karachi.

Results: A total of 102 sodomy cases were reported in various police stations of Karachi during this period. Majority of cases were reported in the police stations belonging to Surjani town (11) followed by Sir Syed (9), Sohrab Goth (9), North Naziamabad (8) and Gulbahar (7). Majority of the convicts belonged to the age range 21-30 years followed by 10-20 years of age. Majority of the accused were found to be living alone without family for earning purpose. All of them were usually of poor socio economic conditions and illiterate. Majority of the couples were found to be related to each other. Presence of semen stains, sexual potency and DNA analysis further confirmed their involvement.

Conclusion: Majority of the accused were of young age, poor, living alone without family, illiterate and from laborer class. These might be the factors responsible for their involvement in alleged sexual behavior.

Keywords: Anal Intercourse, Homosexual, Medico-legal Section, Police Stations,

How to cite this Article:

Waheed A, Talpur MGA, Khan IA, Ram H, Nezam S, Alam SP. Factors Associated with Sodomy Cases at a Tertiary Care Hospital of Karachi. J Bahria Uni Med Dental Coll. 2021; 11(1):22-26 DOI: https://doi.org/10.51985/VSEL5442

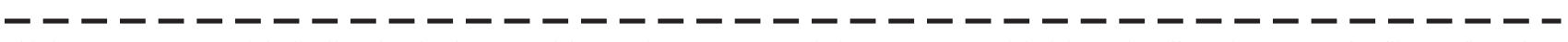
This is an Open Access article distributed under the terms of the Creative Commons Attriution Non Commercial Liciense (http:// creativecommons/org/licences/by-nc/4.0) which permits unrestricted non commercial use, distribution and reproduction in any medium, provided the original work is properly cited.

\section{INTRODUCTION:}

Anal sex is defined as inserting the penis into somebody's anus, or rectum for the purpose of sexual pleasure. ${ }^{1}$ Additional practices encompassing anal sex can be comprised

I - - - - - - - - - - - -

Col (R) Dr Abdul Waheed TI(M)

I Assistant Professor, HoD Forensic Medicine and Toxicology Karachi Institute of Medical Sciences (KIMS), Malir Cantt, Karachi

I Email: chundrigarwaheed@yahoo.com

I Mir Ghulam Ali Talpur

I Medical Officer

Sindh Government Hospital, New Karachi

I Iqbal Ahmed Khan

Senior Lecturer, Department of Forensic Medicine

Fazaia Ruth Pfao Medical College

I

Hari Ram

Demonstrator

I Shaheed Mohtarma Benazir Bhutto Medical College

I Shahid Nezam

I Senior Medico-Legal Officer

I Abbasi Shaheed Hospital, Karachi

I Syed Pervaiz Alam

Associate Professor, Department of Forensic Medicine

I

Received: 17-Jun-2020

Accepted: 05-Nov-2020 of fingering the anus, using sex toys for anal insertion, oral sex executed on the anus, and pegging. ${ }^{2}$ Although ${ }^{3,4}$ anal intercourse generally means penile-anal penetration, whereas anal sex depicts any sort of anal sexual activity performed between couples. ${ }^{2-4}$

Although anal sex is generally allied with male homosexuality, various researches indicate that it can also be associated with heterosexual relationships. ${ }^{5}$ People may feel sexual satisfaction from anal sex mainly by stimulating anal nerve endings, and orgasm may be accomplished through anal penetration of the prostate in males, indirect stimulation of the clitoris or vagina in females, and other sensory nerves (specifically the pudendal nerve). ${ }^{2,5}$

As with vaginal sexual activity, anal sex candidates are also at danger of getting sexually transmitted infections (STIs). ${ }^{5}$ Anal sex is believed to be a risky sex activity due to the hazard of damage to anus and rectum. Anus and rectum are very delicate body parts and do not have lubrication like the vagina gives, so they can be torn easily and can transmit infection, particularly if extra lubrication is not done. ${ }^{5,6}$

Strong opinions are often spoken about anal sex. It is controversial in various cultures, especially with respect to religious prohibitions. This is usually due to prohibitions against anal sex or instructions about the procreative purpose 
of sexual activity. It may be considered taboo or unnatural, and is a crime in some countries, punishable by corporal or capital punishment. ${ }^{4,7}$

The rich nervous supply of anus and rectum can make anal sex more gratifying for men or women., ${ }^{2,57}$ The internal and external sphincter muscles of anus are sensitive tissues enriched with many nerve endings thus provide pleasure or pain via. 2,5

Heterosexual anal intercourse (HAI) is also not an uncommon behavior with $36 \%$ of women and $44 \%$ of men (25-44 years old) in the United States reporting ever having HAI in their lifetime. There is evidence that the prevalence of HAI may be increasing in recent years, which may be due to a true increase in the behavior over time or heterosexuals becoming more comfortable reporting the behavior. ${ }^{7,8}$

Reports concerning the prevalence of anal sex among gay and other men are found to be variable. A survey in The Advocate in 1994 specified that $46 \%$ of gay men desired to penetrate their partners, while $43 \%$ desired to be the receptive partner. Other links suggests that nearly three-fourths of gay men have performed anal sex at least one time, with similar percentage contributing as tops and bottoms. ${ }^{9}$ According to the 2012 NSSHB sex survey in the U.S; high prevalence of anal sex among gay men has been reported with $83.3 \%$ of the men having performed anal sex in the insertive way and $90 \%$ in the receptive way. Majority reported recent performance even as within 30 days or less. ${ }^{10}$

Frequency of anal sex is increasing nowadays because of the increased viewing of anal pornography videos among men. Seidman et al. reported that "cheap, accessible and, especially, interactive media have allowed many more people to view pornography", and this modern way of producing pornography, in which buttocks and anus become more eroticized, has led to a significant increase in or obsession with anal sex among men. ${ }^{11}$

Assuming the increased prevalence of sodomy cases in our population, this study was especially designed to retrospectively observe the sodomy cases brought at medico legal department of Abbasi Shaheed Hospital for examination, from various police stations of Karachi, Pakistan and its associated factors.

\section{METHODOLOGY:}

This was a single centered retrospective study and data was collected from medico legal section of Abbasi Shaheed Hospital, Karachi, from a period of January 2016 till December 2018. An inclusion criterion was all the anal sex cases performed without consent irrespective of age and gender based on Karachi population. Sodomy performed with consent was excluded. All the other type of sexual behaviours were also excluded. There are about 150 police stations in Karachi. Medicolegal cases of more than 45 police stations cases are reported at Abbasi Shaheed Hospital
(ASH). ASH deals from district central, east \& west of Karachi, the important police stations included were Nazimabad, North Nazimabad, Hydri Market, Paposh Nagar, Gulbahar, Rizvia, Taimorea, Sir Syed, Shahra-e-Noor Jahan (SNJ), Orangi Town, Pakistan Bazaar, Iqbal Market, Mominabad Town, Peerabad, Manghopir, Khawaja Ajmir Nagri, New Karachi, Surjani Town, Site Area, Pakistan Colony, Pir Islamb bux Colony (PIB), Sohrab Goth, Site Super Highway Industrial Area (SSHIA), Sachal Goth, Gadap City, Federal B. Industrial Area (FBIA), Gabol, New Karachi Industrial Area (NKIA), Smanabad, Gulberg, Ysuif Plaza, Azizabad, Johar Abad, Aziz Bharti, Gulshan-e-Iqbal, Mobin Town, Sharifabad, Gulistan-e-Johar, Gulshan-eMaymar, Bilal Colony.

A total of 102 cases of sodomy were reported in the above police stations of Karachi in the specified time period.

Detailed information regarding time and place of incidence, area of residence, bath history and relationship with the passive agent was gathered from the register for Accused. Findings of physical examination such as any signs of local injury, scratches \& bruises marks, development of secondary sexual organs, presence of any abnormality like hernia, hydrocele, varicocele was also collected. Penile erecting capacity was also evaluated and mentioned in the register. Evidences were also collected for presence of any trace elements like semen, hairs were taken from anal region both superficial and deep. Preliminary clinical examination was also conducted. In case of disappointing results of the clinical examination, DNA test of suspicious active agents/accused was carried out for confirmation. Data was entered and analysed using SPSS version 22 by calculating simple frequencies and percentages.

\section{RESULTS:}

A total of 102 sodomy cases were found to be registered at medico legal department of Abbasi Shaheed Hospital, Karachi brought from various police stations of Karachi during a period of Jan 2016 till Dec 2018. Total $99 \%$ cases were found to be homosexual in nature while only 1 case was registered as heterosexual in nature. All were residents of Karachi. Sodomy cases were reported to hospital on same day (the day the anal sex was performed). Time elapsed between anal sex and examination was observed to be ranged from 2 to 12 hours. Majority of cases were examined within 3-4 hours. Majority of the convicts belonged to the age range of 21-30 years followed by 10-20 years of age. (Fig1) Mean age of the convicts was calculated to be 23.19 years. All the active agents were usually of poor socio economic conditions and illiterate. Majority of the active agents were found to be living alone without family for the earning purpose. Detailed demographic features of the agents are shown in Table-1. Table-2 shows the findings of preliminary physical and clinical assessment of active agents. Semen stains were found on the cloths of 30 (29.4\%) whereas 
Table 1 - Demographic Features of the accused N=102

\begin{tabular}{|l|c|}
\hline Characteristics & N (\%) \\
\hline Age Range & \\
\hline $10-20$ & $26(25)$ \\
$21-30$ & $52(50.9)$ \\
$31-40$ & $4(3.92)$ \\
$41-50$ & $10(9.8)$ \\
$51-60$ & $4(3.92)$ \\
$61-71$ & $6(5.82)$ \\
\hline Gender & \\
\hline Males & $101(99)$ \\
Females & $1(1)$ \\
\hline Socioeconomic conditions & \\
\hline Good & $00(00)$ \\
Poor & $102(100)$ \\
\hline Education & \\
\hline Nil & $80(78.43)$ \\
Primary & $17(16.6)$ \\
Secondary & $5(4.90)$ \\
\hline Employment status & \\
\hline Employed & $99(97.05)$ \\
Unemployed & $3(2.94)$ \\
\hline Living & $14(13.72)$ \\
\hline With Family & $88(86.27)$ \\
Alone & \\
\hline
\end{tabular}

Table 2- Preliminary Physical and clinical assessment of accused $(\mathrm{N}=102)$

\begin{tabular}{|l|c|c|}
\hline Findings & Positive & Negative \\
\hline Semen stain & $30(2.94)$ & $72(70.5)$ \\
\hline Blood stain & $12(11.7)$ & $90(88.2)$ \\
\hline Bruise/scratch marks & $14(13.7)$ & $88(86.2)$ \\
\hline Penile erection capacity & $102(100)$ & $0(0)$ \\
\hline Any disease e.g., hydrocele, hernia & $0(0)$ & $102(100)$ \\
\hline Secondary sexual characteristics & $102(100)$ & $0(0)$ \\
\hline Potency/Penile erection & $102(100)$ & $0(0)$ \\
\hline
\end{tabular}

blood stains were found in $12(11.7 \%)$ out of 102 active agents. Scratch marks were observed in 14 active agents. On preliminary clinical assessment, all the convicts were found to be sexually potent. Secondary sexual characteristics were well developed in all. DNA of only suspicious 14 accused was sent for laboratory analysis out of 102. (Table 2). Majority of cases were reported in the police station belonging to Surjani town (11) followed by Sir Syed (9), Sohrab Goth (9), North Nazimabad (8) and Gulbahar (7). Majority of the cases were brought to ASH by the Police. However, few cases were also brought by relatives with police letters. It was also observed that majority of cases
Table-3 Information gathered from register related to Accused

\begin{tabular}{|l|c|}
\hline Associated Factors & No (\%) \\
\hline Place of incident & \\
\hline Victim's house & $5(4.9)$ \\
\hline Accused house & $3(2.9)$ \\
\hline Isolated Place & $89(87)$ \\
\hline Hotel & $5(4.9)$ \\
\hline No of partners & \\
\hline Single & $93(91)$ \\
\hline Multiple & $10(9.8)$ \\
\hline Relationship with Passive partner & \\
\hline Related & 95 \\
\hline Non-Related & 7 \\
\hline Employment type & \\
\hline Labourer & 78 \\
\hline Fruit seller & 4 \\
\hline Driver & 4 \\
\hline House-Servant & 11 \\
\hline Shopkeeper & 5 \\
\hline
\end{tabular}

were not brought on time by Police as they usually try to negotiated with both parties. Table- 3 shows some more information related to accused gathered from register.

\section{DISCUSSION:}

According to this study, 102 cases of sodomy were reported to medico legal section of a tertiary care hospital for medico legal examination from various police stations of Karachi. $99 \%$ cases were homosexual in nature while only 1 case was of heterosexual in nature. Of the data that are available, it appears a significant and increasing minority of heterosexuals have ever practised anal intercourse. Among homosexual men, most, but not all, report anal sex, with large proportions of men engaging in both insertive and receptive anal intercourse. ${ }^{12}$

In our country's Khyber Pakhtoon Khawa Province (KPK), it is outwardly common that Pashtun males do sexual activity with young boys which is suggested by IRIN as a "a practice now deeply rooted in the local culture."13 The Internet is promoting "solidarity" among homosexuals in Pakistan. ${ }^{13,14,15}$ Online chat rooms offer a protective and unidentified platform for middle and upper class gay men. ${ }^{14}$ According to a British Broadcasting Corporation (BBC) article (2005), increased number of homosexual couples are residing together in Pakistan's big cities such as Karachi and Islamabad. ${ }^{15}$ However, one of Guardian article published in 2006 reported that it is "rare" for same sex couples to reside together ad majority have to finally marry women so as to avoid from any scandal in their family. It is well stated that the environment in larger cities such as Islamabad, Karachi and Lahore is more bearable as compared to rural areas where the extreme conservatism is present and homosexuals remain 
"closeted. ${ }^{16}$ There are no reports on female homosexuality, in Pakistan, the females inhabit mainly, a strictly private realm. ${ }^{17}$

Homosexuals who are not liked by their families also have to establish themselves on their own. This growth is impossible in the homosexual environment or in rural areas of country. The country's intentional blindness has provided space sufficient for gays and lesbians. They live together as couples, though discreetly. ${ }^{18}$

In this study, mainstream population of the active agents/accused fitted to the age range of 21-30 years followed by 10-20 years of age which is quite a young age. Researches on the premarital sexual activity of adolescents has shown that it is potentially risky and harmful ${ }^{19}$, because of the risk of sexually transmitted infections (STIs) and unwanted teenage pregnancies as identified in countries such as Great Britain and the United States. ${ }^{20,21,22}$ Risky sexual activities of young adults, usually executed as precocious sexual onset (i.e., first intercourse before the age of 15; erratic condom use, and many sexual partners can directly lead to the incidence of STIs including HIV. ${ }^{23,24}$

In this study, majority of the cases were of homosexual. Only 1 case of heterosexual anal case was reported. Still strict social customs are present for females, which keep them away from any sex activity and avoid indulging in multiple sex partners ${ }^{25}$ whereas boys have more liberty for sex. Boys are generally socialized in more sex-positive peer contexts and are pressurized by their fellow friends to indulge in sexual activity. ${ }^{26}$ This is the reason boys are more reported to be involved in sexual activities. Gender differences in sexual behaviors found in our societies are basically due to cultural and socialization factors. ${ }^{27}$

In our study, majority of cases were reported in the police station belonging to Surjani town (11) followed by Sir Syed (9), Sohrab Goth (9), North Nazimabad (8) and Gulbahar (7). The reason for more incidences of sexual abuse cases in these areas could be because of low socio demographic type of these areas. ${ }^{28}$

Reasons of accused for involving in unnatural sex activities identified by this study were living alone without family, lack of education as majority of the active agents were living alone in the city for earning purpose but were illiterate. Disturbed family relationships can cause disturbances in emotions which are assumed to be developed in early childhood and which in a majority of cases can cause the anti-social, sexual and violent behavior at a young age. ${ }^{29}$ Delayed reporting of sexual assault cases can result in loss of essential evidences required. Hence; early reportage and inspection of cases must be done. ${ }^{30}$

It is highly recommended to conduct this study gathering data from interior areas of Pakistan. Furthermore, more demographic characteristics of accused i.e. race and family atmosphere should also be incorporated. Smaller sample size and data collection from single center are major limitations of present study.

\section{CONCLUSION:}

Majority of the accused were of young age, poor, living alone without family, illiterate and from labour class. These might be the factors responsible for their involvement in alleged sexual behavior.

Authors Contribution:
Abdul Waheed: Conceived the idea, writing of manuscript,
SPSS analysis and supervised the study
Ghulam Ali: Proposed the study design and collection data
Iqbal Ahmed Khan: Helped in data collection procedure and
entry of data in Excel
Hari Ram: Critically analyzed the manuscript, Bibliography
Shahid Nezam: Helped in data analysis and critically analyzed
the manuscript
Pervaiz Alam: Helped in data entry and analysis
REFERENCES:

1. WeiteN W, Lloyd MA, Dunn DS, Hammer EY.Psychology applied to modern life:Adjustment in the 21st century. Cengage Learning; 2016: P.349.

2. Ybarra ML, Rosario M, Saewyc E, Goodenow C. Sexual behaviors and partner characteristics by sexual identity among adolescent girls. Journal of Adolescent Health. 2016;58(3):3106.

3. Markland AD, Dunivan GC, Vaughan CP, Rogers RG. Anal intercourse and fecal incontinence: evidence from the 2009-2010 National Health and Nutrition Examination Survey. The American journal of gastroenterology. 2016;111(2):269.

4. Anal sex, defined. Discovery.com. Archived from the original on June 13,2002. Retrieved July 23,2013.

5. Wamoyi J, Mongi A, Sally M, Kakoko D, Shamba D, Geubbels E, Kapiga S. A qualitative study of discourses on heterosexual anal sexual practice among key, and general populations in Tanzania: implications for HIV prevention. BMC public health. 2015;15(1):417.

6. Krasner RI. The Microbial Challenge: Science, Disease, and Public Heatlh. Jones \& Bartlett Publishers; 2009:416-17.

7. Hess KL, DiNenno E, Sionean C, Ivy W, Paz-Bailey G, NHBS Study Group. Prevalence and correlates of heterosexual anal intercourse among men and women, 20 US cities. AIDS and Behavior. 2016;20(12):2966-75.

8. Hess KL, DiNenno E, Sionean C, Ivy W, Paz-Bailey G, NHBS Study Group. Prevalence and correlates of heterosexual anal intercourse among men and women, 20 US cities. AIDS and Behavior. 2016;20(12):2966-75.

9. Vansintejan J, Vandevoorde J, Devroey D. The gay men sex studies: Anodyspareunia among Belgian gay men. Sexual medicine. 2013;1(2):87-94.

10. Dodge B, Herbenick D, Fu TC, Schick V, Reece M, Sanders S, Fortenberry JD. Sexual behaviors of US men by selfidentified sexual orientation: Results from the 2012 National Survey of Sexual Health and Behavior. The journal of sexual medicine. 2016;13(4):637-49.

11. Steven Seidman,Nancy Fischer;Chet Meeks. Introducing th new sexuality Studies (2nd edi).2011. Routledge.pp.108-112. 
12. Heywood W, Smith AM. Anal sex practices in heterosexual and male homosexual populations: a review of populationbased data. Sexual health. 2012;9(6):517-26.

13. United Nations. Integrated Regional Information Networks (IRIN). "Pakistan: Focus on Gay Rights."10 May 2005. [Accessed 14 Nov. 2007]

14. The Guardian [London]. Declan Walsh. "Pakistani Society Looks Other Way as Gay Men Party."14 March 2006. [Accessed 14 Nov. 2007]

15. British Broadcasting Corporation (BBC). "Bail for Pakistan "Same-Sex" Pair."28 June 2007. [Accessed 14 Nov. 2007]

16. United Nations (UN). Integrated Regional Information Networks (IRIN). "Pakistan: Marginalised Male Sex Workers Vulnerable to HIV/AIDS."21 september 2006. [Accessed 14 Nov. 2007]

17. Kennedy, Miranda Open secrets. The Boston Globe. (2004, 11. July). Available at http://www.boston.com/ news/ globe /ideas/articles/2004/07/11/open_secrets/?page=full [retrieved 1. February 2013]

18. Ladly, Meghan Davidson Gay Pakistanis, still in shadows, seek acceptance. The New York Times. (2012, 3. November). Available at http://www.nytimes.com/2012/11/04/ world/asia/gays-in-pakistan-move-cautiously-to-gainacceptance. $h$ tml? pagewanted $=$ all\&_r=0 [retrieved 5. February 2013]

19. Fergus S. ZimmermannnM. A, Caldwell CA Sexual risk behavior In adolescence and young adoulthood. American Journal of Public Health. 2007;97(6):1096-10.

20. Jonas K, Crutzen R, van den Borne B, Sewpaul R, Reddy P. Teenage pregnancy rates and associations with other health risk behaviours: a three-wave cross-sectional study among South African school-going adolescents. Reproductive health. 2016;13(1):50.

21. Forhan S.E., Gottlieb S.L., Sternberg M.R., Xu F., Datta S.D., McQuillan G.M., Berman S.M., Markowitz L.E. Prevalence of Sexually Transmitted Infections Among Female Adolescents Aged 14 to 19 in the United States. Pediatrics. 2009; 124:1505-12.
22. Neal S, Matthews Z, Frost M, Fogstad H, Camacho AV, Laski L. Childbearing in adolescents aged $12-15$ years in low resource countries: a neglected issue. New estimates from demographic and household surveys in 42 countries. Acta obstetricia et gynecologica Scandinavica. 2012;91(9):11148.

23. Boislard M.A., Poulin F., Kiesner J., Dishion T.J. A Longitudinal Examination of Risky Sexual Behaviors among Canadian and Italian Adolescents: Considering Individual, Parental, and Friend Characteristics. Int. J. Behav. Dev. 2009;3 (3):265-76.

24. Xu R, Dai W, Zhao G, Tu D, Yang L, Wang F, Cai Y, Lan L, Tan H, Liu A, Feng T. Early sexual debut and HIV infection among men who have sex with men in Shenzhen, China. BioMed research international. 2016.

25. Fourcroy JL. Customs, Culture, and Tradition-What Role Do They Play in a Woman's Sexuality?. The journal of sexual medicine. 2006; 3(6):954-9.

26. Bingenheimer JB, Asante E, Ahiadeke C. Peer influences on sexual activity among adolescents in Ghana. Studies in family planning. 2015;46(1):1-9.

27. Chaplin TM. Gender and emotion expression: A developmental contextual perspective. Emotion Review. 2015;7(1):14-21.

28. Al-Azad MA, Raman Z, Ahmad M, Wahab MA, Ali M, Khalil MI. Socio-demographic characterstics of alleged sexual assault (rape) cases in Dhaka city. Journal of Armed Forces Medical College, Bangladesh. 2011;7(2):21-4.

29. Cowley J. Youth in a Delinquent Society [Online] .4th International, Fall 1955:111- 119. Available from: https://www.marxists.org/history/etol/ newspape/fi/vol16/no04/cowley.html. Accessed on: 25ht January 2020.

30. Tamuli RP, Paul B, Mahanta P. A statistical analysis of alleged victims of sexual assault a retrospective study[Online]. J Punjab Acad Forensic Med Toxicol 2013;13(1):7. Available from:http:// medind.nic.in/jbc/t13/i1/jbct13i1p7.pdf. Accessed on: 25th January 2020. 